\title{
The State of Primary Education in Nigeria: A Critical Review
}

\author{
Babatunde Adeniyi Adeyemi* \\ Professor, Institute of Education, Obafemi Awolowo University, Ile-Ife, Osun State Nigeria
}

*Corresponding Author

Babatunde Adeniyi Adeyemi

\section{Article History}

Received: 11.06 .2020

Accepted: 22.06 .2020

Published: 25.06.2020

\begin{abstract}
The study examined the state of primary education in Nigeria considering various indices directly related to education at this level. The study looked into the advent of primary education in Nigeria, its purpose as well as the various subjects through which knowledge and cultural values are to be passed unto the younger ones. The study examined the contributions of parents, funding, government, curriculum, supervision, quality of primary school teacher, classroom size, poverty, ICT, text and exams, the political system, infrastructural facilities among others, to the present state of primary education in the country. The study further examined the challenges emanating from the different indicators relating to primary education and finally proffers solutions to salvage the situation.
\end{abstract}

Keywords: Primary, Education, Nigeria.

\section{THE CONCEPT OF PRIMARY EDUCATION}

Primary education refers to the first stage of formal education. It is the stage that comes up after the pre-primary. The primary school is a school where children within the ages of 5-12 are given formal education. In Nigeria, it is the school which children attend before they go to secondary school. In the primary school, children are exposed to a variety of subjects such as indigenous languages, English Language, French, Arabic, Mathematics of Numeracy, Basic Science, Social Studies, Health Science, Agricultural Science, Local Craft and a host of other disciplines with a view to equipping them with basic knowledge and skills which would help them to lead meaningful life in the future.

In the colonial days, the purpose of primary education was basically that of reading, writing and arithmetic. Children were then basically educated to be able to read, importantly in the white man's language (English), so as to enable them to be able to communicate easily with the Europeans who were then the colonial masters, and to be able to write and do some arithmetic so as to enable them to serve other civil and domestic purposes of the colonial master satisfactorily. After independence, the stakeholders in primary education found that the purpose of primary education was then was inadequate to meet the needs of the independent Nigerian child. Thus a new national policy on education was planned and formulated for schools in Nigeria.

According to the national policy on education in Nigeria 2014 [1], the purposes of primary education in Nigeria include the teaching of permanent literacy, numeracy and the ability to communicate in a child's native language and English language effectively; laying a sound basis for scientific and reflective thinking; encouraging a sense of belonging-citizenship education; training the children in moral and character training; the ability to adapt to changing environment as well as building a solid foundation for secondary education.

There has been a lot of controversy on whether the standard of primary education has fallen or not. A school of thought is of the opinion that the pupils who had primary school education today are not as literate and versatile in doing many things as those of the sixties to eighties. They opined that even the conduct of the learners then was better. They were humbler, obedient, respectful, and morally sound than those of today. The other school of thought are of the opinion that primary school pupils are more knowledgeable, more sociable and intellectually shaper than those of the past during this information and communication technology era. For instance, they believed that the children of today can operate the

Copyright @ 2020: This is an open-access article distributed under the terms of the Creative Commons Attribution license which permits unrestricted use, distribution, and reproduction in any medium for non commercial use (NonCommercial, or CC-BY-NC) provided the original author and source are credited. 
computer very well, they handle sophisticated things and play computer games which looks like mystery to the pupils of those days. This paper looks at both sides of the argument with a view to drawing conclusions on the writer's perspective on the matter.

\section{Parents}

The parents of today are quite different from those of the yesteryears. Firstly, the material aspirations of the people in those days were quite limited. Their zeal to cater for their children was much greater than their desire to pursue material things. They were so concerned about the education and training of their children to the extent that they could sell their clothes, jewels and other valuables in order to finance their children's education. The fact that some of them were not opportune to acquire formal education to a basic level or totally at all, made them to do all they could to ensure that their children are well educated. Today, the desire for material acquisition is high. There are parents who, because of the demands of their jobs or the desire to reach the top of their career, hardly have the much time to take the much needed care of their children although many parents especially the literate ones do desire that their children are well educated yet, some are non-challant about these cases in Nigeria. According to UNICEF [2], about 1.3 million children are still out of school. This is quite alarming and shows a laissez-faire approach to children education in Nigeria.

Another factor which can be attributed to the falling standard of primary education is parental attitude to the implementation of the medium of instruction in the primary school. Oderinde and Oladimeji [3] observed that although the national policy on primary education in Nigeria specifies that learning in the lower primary schools should be facilitated through the use of mother tongue, parents do not want their children to be taught in the native language in primary school, even though it was found that children taught in the language of the immediate environment perform better than those taught in the official language of the nation.

Although it is a welcome thing for parents to be actively involved and to encourage learning in their children, yet, they should not play such roles that may negatively affect the proper implementation of government's policy on children education and eventually adversely affect the output if our primary schools, this was not so in the past.

\section{Funding}

Generally speaking, the percentage of the Nigeria national budget that goes to the education sector in developing countries cannot be said to be okay. Even then in Africa, some countries still perform better than others in their financial allocations to the educational sector. Ghana, and South Africa are among African countries which, on a regular basis, allocate not less than $20 \%$ of their annual budget to education. In Nigeria, the case is different, only $7.2 \%$ of the annual budget (620.5 billion naira) was allocated to education in 2019. This was far from UNESCO's recommendation of $15 \%$ to $20 \%$ of the national annual budget and this was even decreased to $6.2 \%$ in year 2020 budget [4]. This is grossly inadequate for all the tiers of education to perform effectively how then can the school learners outwit the previous performance under a decreasing finance?

\section{Government}

The determination of the government of today to improve the educational sector could not be said to have the will power to invest in and develop education as it was in the pre-independent era. According to Oluwasanmi [5], Nigerian leaders make series of electioneering promises but do not fulfil them when they get to office. He observed that this has made lack of good education a bane in the country.

In the 1970's the federal government made a policy on universal primary education which was launched in Sokoto state in 1976 by the then head of state, General Olusegun Obasanjo with a view to increasing pupils enrolment and improving primary education among other things. Later, it domesticated the Universal Basic Education Programme. These policies made it mandatory for the children of school age to acquire the primary and basic education compulsory but the will power to enforce these by the consecutive government has not been there, where then lies the improvement in the products of schools?

The issue of quality control in primary education is a major concern if the product of primary schools must improve. Before now, each pupil worked hard to attain the standard expected of them not only in daily school activities, but also for promotion, but today, pupils are given automatic promotion to the next class whether they meet the basic requirements for the next class or not. Since the content to be learnt in the next class is basically more difficult than the class they have failed, the tendency is that the learnings of such children and consequently their output when granted automatic promotion would be adversely affected.

\section{Multiple Curriculum}

In Nigeria, there are series of curricula of study for learners in the primary school. Among these are the NERDC curriculum, the CESAC curriculum, and so forth. By this it appears that the federal government is inconsistent about 
what the learner should learn. This is not the only problem with the curriculum, the texts to be used for study are often changed mid-way between within an academic year, when this does not happen, the learners may not be informed early enough about the change. These were not so in the past and all these are expected to have marked effects on the output of the primary school.

\section{School Supervision}

The inspectorate unit of the ministry of education is the school supervisory unit. It is saddled with the responsibility of monitoring the activities of the schools to ensure that each school's daily programme is implemented in consonance with the curriculum. In those days the inspectors did their job without fear or favour but and the management of our primary schools worked hard without interference but now that we have our self-government, some influential, highly placed, and powerful people in government sometimes do not allow the supervisors and other primary school officials to perform their duties as expected, for instance, if their wives, daughters and close relations who are primary school teachers are posted to rural communities where their services are required, they obtain an order that they be posted or returned to urban areas where there exist a reasonable number of teachers, and where their services may be less required. Equally to correct or discipline such staff members becomes difficult for the head teacher who may be punished indirectly by way of being transferred to a rural area as a result.

\section{Quality of Primary School Teachers}

The quality of teachers who teach in the primary schools in Nigeria is a point of concern. Quite a number of the state governors in the recent past have acknowledge that the quality of teachers in the primary school perform below expectation when presented with primary school tests [6].

Despite the reported low quality of primary school teachers in a number of the states in Nigeria, the training of primary school teachers today is not taken quite seriously as expected. Besides, many of the teachers in the primary school are not genuinely interested in teaching. They intended to use teaching as a stepping stone to a greener pasture. The teachers of those days choose to be trained as teachers and went into the teaching field on personal interest and this motivated them to be committed to doing the job with the required zeal and attention it deserved. Today, things have changed. Quite a number of young people go into the teaching field not out of personal devotion, but because of the dart of jobs, as a result, their productivity cannot be the same and this has the consequence of negatively affecting the quality of teaching and learning and hence the output.

The training required for qualification as a teacher today is quite different from that of those of those days. In the early 60's and after, before a teacher trainee would be professionally qualified, he had to undergo a number of professional teachers courses such as the Teachers Grade III, Grade II and the Nigeria Certificate in Education (NCE) before proceeding to the university to acquire the first degree. Today, a fresh school certificate holder goes straight to the NCE College and in three years, he or she becomes a professionally qualified teacher. Worse still, many of the courses that were compulsory for graduation those days, which made the student-trainee to work very hard to ensure qualification has been scrapped. All these affect the quality and efficiency of the primary school learners.

\section{Classroom Size}

An important reason why the products of primary school today is quite low when compared with those of the past is the classroom size. In those days, the size of the classroom was small and the teacher could do a thorough job of educating the children collectively and monitoring their learning individually. Today, things have changed. The classes in primary schools are large. The increasing population as well as increasing demand for children education has caused the number of pupils in a class in the most urban areas to sometimes be embarrassingly too large for proper learning to take place. Indeed, primary school teachers often confessed that their classes are too large to allow the teaching of every pupil properly [7], hence the product of such schools cannot be expected to be of the previous quality.

\section{Poverty}

The beginning of a school session according to Banerji [8], is a season of joy for learners not only because they move from a lower class to higher one, but also because new uniforms, textbooks and stationeries are acquired for children to learn and they are happy. This is not so with the children whose parents did not procure these things for them or those who are outrightly not sent to school. This could be a factor in the achievement and attitude to life after.

He observed that today children perform far below the level of parental expectation. He lamented that half of all the rural primary five pupils could not read the materials in primary two class fluently and that about half of the same group of pupils could solve a basic two-digit subtraction in arithmetic involving borrowing, which is expected to be performed by primary two pupils in India [8]. He noted that under a situation like this, a pupil is not likely to be able to achieve the goal of primary education at the end of the programme. 
Closely related to the above is the home situation which is a factor in learning or otherwise of a primary school pupil. If the home environment is warm and loving, the child learns happily but if the home is hostile and unkind, the child does not learn as expected and the output of such school would be of less quality. In the modern day, divorce is on the increase [9] and the single mothers are also increasingly; violence of various kinds against the child and mothers are increasing all these cannot produce good quality primary school graduates.

\section{The ICT}

There is a common saying today that the world has become a global village. This is because of the technological breakthrough in information and communication technology. The hand set is a common thing not only in the family but also among the primary school children. Indeed, many people, including children, abuse the use of hand set. They stay glued to information and materials in the internet for hours doing what will not benefit them much. Some have thousands of friends and communicate with lots of people on WhatsApp, twitter and Instagram for hours, thus using their precious time on less important things rather that building themselves up academically. This affects the end-products of the primary school.

Besides, if the primary school teachers are not regularly trained to be computer literate, the learners would have access to or tend to know more than their teacher and they may find it difficult to keep the pupils' attention during the class and they may lose interest in their learning [7].

\section{Tests and Exams}

Today, series of tests and examinations are conducted in various primary school class to assess the performance of pupils but to one's surprise, the tests are not used in promoting the learners, whether a child performs well or not, he or she is promoted to the next class at the end of the day. An important purpose of testing the learners which is for placing each learner in the appropriate class is no longer applied. In developed countries of the world, in America for instance, instead of using pupil's performance to place them, it is used to assess the teacher's performance [7]. This was not so in the past, pupils were aware that if their performance does not measure up to standard, they would have to repeat the class and this gingered them to learn.

Examinations are presented to honestly assess the level of understanding and achievement of learners in schools. It is supposed to be prepared and administered in such condition as to make it to truly examine the individual pupils' performance in school. In the days before now, this was religiously done but today, the preparation and conduct of examinations in many of our primary and secondary schools are not in accordance to the laid down rules and regulations. Children are not only allowed but are also encouraged to cheat during tests and examinations. This negatively affects the end products of primary schools because the learners do not have to attend lessons regularly and work hard to perform well in their tests and examinations. They can wangle their way through obtaining good results because some of the stakeholders are there to connive with them to fetch them undesired high performance. This does not only affect their level of understanding but also their conduct since some of them can be arrogant or disobedient to their teachers since they do not have to work hard to pass subject(s) taught by the teacher.

\section{The Influence of Politicians}

The negative influence of politics on Primary education is a point of concern today. It is a common practice during the civilian era to appoint a wrong person in a position of authority. For instance, in Nigeria, a specialist in agriculture could be made to head the education ministry while a lawyer could be appointed to be in charge of the ministry of women and children affairs.

Besides, while the graduates who are professionally trained as teachers are struggling to get employment without success, the relations and associates of politicians who are not professionally qualified get teaching jobs especially in the primary schools with relative ease. This lop-sidedness in appointment as well as improper consideration of people for teaching employment could have negative effects on the quality of primary schools.

\section{The Political System}

The global society is tending towards democratic system of leadership. The democratic political system encourages freedom: freedom of speech, freedom of association, the freedom to make choices among alternatives, freedom from undue parental control and so forth. In the traditional African society, the society and the parents to a large extent control and set the limits, or codes of conducts for their children and they lived within the limits, so the society was moving on as expected. The children were seen to freely mix with the society without hitches whereas those primary school children who are brought up in the freedom packed western system tend to be lazy and have laxities in their conduct. 
Besides, the government itself tends to be quite relaxed about the rule and regulations that govern the schools today. The youth in the higher institutions for instance, wear transparent, too short or too tight clothes to school without adequate control. They go on partying, drinking and doing all sorts of things. Some even engage in secret groups with impurity because the rules and regulations available sets certain limits within which the school authority can operate. Some parents have not helped the situation because some of them do not want their children to be corrected extrinsically. How then can the product of today's primary school be comparable with those of yesteryears in terms of quality and conduct?

\section{Infrastructural Facilities in Primary Schools}

Before now, the society was already adjusted to their mode of teaching and training their children. There were scanty, infrastructural facilities and yet the learners adjusted and learned well. The teacher was the main source of information to the learners. He or she knew this and was always well prepared to ensure that maximum learning took place. Learning was not dependent on electricity or any complex machine, today however, the world has become a global village, modern science and technology, modern modes of information and communication technology has been added to the school curriculum. Without electricity for instance, learning becomes greatly hindered. It is however unfortunate that although the governments of countries found the new addition to the curriculum necessary and introduced them to our primary, secondary and tertiary schools, yet they have not been doing enough to make these aspects of learning to work well. Electricity which is an important service to be used in learning, and modern information and communication technology classes are unfortunately not available in many of our communities in Nigeria, and by extension our schools today. Besides, the equipment to be used for learning are not supplied adequately. So, it is common place to see about five pupils learning with a set of computers instead of an individual pupil having his or her own to learn with. In communities where there is electricity, its supply is epileptic and cannot be relied upon for use during specific lesson periods.

\section{The Society}

There is no gainsaying that the Nigerian society of yesteryears is quite different from that of today in terms of morality. In the yesteryears, the child was raised by the community and not by the parents only. As a result, any relation in the neighbourhood could correct, rebuke or even punish an errant child in the society then. That makes the (primary school) child to be cautious of their behaviour in the society. Today, things have changed, many of the parents do not want their children to be corrected even by their teachers not to talk of neighbours. Besides immorality is increasing in societies today [10] and the primary school pupils are not left out. Some of them are in secret cult, disobedient to their teachers, and so forth, thus, the end-product of the primary school cannot be the same as before.

\section{Suggested Solutions}

The government is encouraged to increase its budgetary allocation to the education sector. In line with this, the percentage of the education budget that goes to the primary level of education must also increase to at least $20 \%$ of the countries annual budget, because primary education is the foundation stage which has to be solidly laid so as to have a firm education structure.

Besides, the issue of many curricular needs to be addressed by the government. It needs to reform the existing curriculum so that it will be more activity oriented and properly suit the primary school. Government should enforce the implementation of Universal Basic Education in Nigeria. Every child of school going age should be mandated to acquire basic education and errant disobedient parents must be made to face the wrath of the law.

Government should ensure that examination malpractice become a thing of the past. All measures should be put in place to ensure this and errant administrators, teachers and those who connive with them should be made to face the wrath of the law. Also, the inspectorate division of the ministry of education should be well equipped and given free hands as of old, to ensure quality supervision of primary education the politicians should not be allowed to interfere unnecessarily in the workings of the primary school. Besides, the primary school should be adequately equipped with learning resource materials to facilitate effective learning.

The government of Nigeria should sincerely ensure a great reduction in poverty among the populace. This will help the parents to be able to enjoy the basic necessities of life and to support their children education as deemed necessary.

The parents of school pupils need to be sensitised on necessity to ensure that their children have at least the basic level of education. Their support for children education should be enlisted and the consequences of not allowing their children to attend school should be well highlighted. Also, the parents should ensure that the home is made to be a loving one, it should be a place of comfort and joy for the pupils. Also, the parents should support learning in their children. 
On the issue of teachers' quality and quantity, the appropriate education authority should be allowed to recruits, discipline and sack any teacher who is not performing up to expectation. There should not be undue interference from the society which can mar the effective functioning of our schools. Also, provision should be made to employ adequate number of teachers not only in the urban but also in the rural areas. The teacher needs to ensure that effective learning takes place in schools. They need to prove that they are professionally qualified to do this. They must make sure that each child is encouraged not only to learn theories but also to apply whatever they have learned in their day-to-day lives.

The issue of corruption needs to be seriously tackled by the government. It must not be treated with kid-gloves. Our society needs to return to the past. People must be concerned with the overall welfare of the society rather than individuals. Also, morality must be re-established. Our youths need to live lives devoid of greed, ritual killings, sexual lust and the get-rich-quick type of life. The society must know the peace which it once enjoyed. Then our primary schools would turn out quality products as it did before.

\section{REFERENCES}

1. Federal Republic of Nigeria. (2014). National Policy on Education in Nigeria; Lagos: Government Press Limited.

2. UNICEF, Nigeria. (2017). Out of school children in Nigeria Education, UNICEF Nigeria. Available online at: https://www.unicef.org.

3. Oderinde, D. B., \& Oladimeji, A. J. (2018). Repositioning childhood education through parents' and teachers' awareness and use of the mother tongue in nursery and primary school in Kwara State, Nigeria. Journal of Early Childhood Association, 7(2):585-597.

4. Ameh, J., \& Aluko, O. (2019). 2019 budget; Education gets 620.5bn, against UNESCO's advice. The Punch, January 04. Available online at: https.punchng.com

5. Oluwasanmi, B. (2020). Buhari's false promise: "I will move 100 million Nigerians out of Poverty in Ten Years". Domestic Politics in Sahara Reporters Daily Newspaper. May 04. Available online at: https://www.Saharareporters.com

6. Markus, E. D., Agee, J. T., \& Jimoh, A. A. (2017). Flat control of industrial robotic manipulators. Robotics and Autonomous systems, 87, 226-236.

7. Chen, G. (2019). 10 major challenges facing public schools. https//www.publicschoolsreview.com

8. Banerji, R. (2017). Challenges to primary education. Available online at: https.www.palnetwork.org

9. United Nations (2002). Highest divorce rate/Guinness World Records. Available online at: https:www.guinnessworldrecords.com

10. Deeper Life Bible Church. (2020). It is a preserve generation, beware: In Christian Women Mirror, Lagos; Life Press Limited. March. 